\title{
Future of Renewable Resources in an Area Burdened by Brown Coal Mining
}

\author{
Jaroslava Vráblíková, Petr Vráblík, Eliška Wildová, Miroslava Blazková \\ Department of Natural Sciences, Faculty of Environment, J. E. Purkyně University in Ústí nad Labem, \\ Ústí nad Labem, Czech Republic \\ Email: Wildova.Eliska@gmail.com
}

How to cite this paper: Vráblíková, J., Vráblík, P., Wildová, E. and Blazková, M. (2017) Future of Renewable Resources in an Area Burdened by Brown Coal Mining. Natural Resources, 8, 757-766. https://doi.org/10.4236/nr.2017.812046

Received: November 14, 2017 Accepted: December 16, 2017 Published: December 19, 2017

Copyright $\odot 2017$ by authors and Scientific Research Publishing Inc. This work is licensed under the Creative Commons Attribution International License (CC BY 4.0).

http://creativecommons.org/licenses/by/4.0/

(c) (i) Open Access

\begin{abstract}
This contribution is focused on a possible utilization of renewable energy resources in the Podkrušnohoří region (Chmomutov, Most, Teplice, Ústí nad Labem districts) in the northern part of the Czech Republic after the end of brown coal mining in 2055. Results of the research describe current share of renewable energy resources (solar, wind, water, biogas) in the model area, and a future energy potential in order to ensure sustainable development of an anthropogenically burdened region. Aim of this contribution is to determine, which renewable energy resources would be the most suitable for energy production after the end of brown coal mining. It also describes current and possible use of geothermal power as there are registered heat flow anomalies in the area.
\end{abstract}

\section{Keywords}

Alternative Energy Resources, Brown Coal, Power Stations, Podkrušnohoří Region

\section{Introduction}

Renewable energy resources are mostly dependent on geographical, geomorphologic and climatic conditions. However, not every area can meet suitable conditions, and after future attenuation of energy production from fossil fuels, these areas will be dependent on energy importation. Therefore, every area should be treated individually with respect to its current economical, social, and environmental conditions to secure sustainable development of the region. Very specific areas are those affected by anthropogenic activities, such as coal mining. Heir structure has been destructed and their future development is unstable. An example 
of this area is located in the northern Bohemia under the Ore Mountains (Chomutov, Most, Teplice, and Ústí nad Labem districts), where brown coal is surface mined for over 200 years. The area was once a part of the so-called Black Triangle which connected mining areas in Central Europe with the most polluted environment. The greatest problem in the entire Black Triangle area was air pollution from sources at thermal power stations, heating plants, open-cast coal mines, and chemical plants. The long-term burden on the environment in the previous period was the reason for its deterioration, and some of its components were also reflected in inhabitants' poor health. Thanks to the reclamation and restoration processes, the area is successfully restored; however the future of energy production after the coal mining is not taken into an account.

Not only the North Bohemia region, but the Czech Republic in general is dependent on energy from the heat power plants. Today, the CEZ Group operates coal-fired power stations and heating plants in a total of 13 localities on the territory of the Czech Republic. Most of them burn North Bohemian brown coal and, for practical reasons, they are situated in the immediate vicinity of large quarries in North and Northwest Bohemia. They include the following coal-fired power stations: Ledvice, Pocerady I., Pocerady II., Prunérov, Tusimice I. and Tusimice II., which currently have an installed capacity in all power station blocks of $3620 \mathrm{MW}$ [1]. To achieve the objectives of sustainable development in the region, we must take gradual steps to secure the creation and development of legislation and measures in the price area, and limit the use of non-renewable sources. The main measures that will help us achieve these objectives are fuel economy and meeting consumption needs through renewable sources. From the perspective of sustainable development, it would be appropriate to differentiate fiscally between non-renewable and renewable sources. Impose tax penalties on non-renewable sources, particularly carbonaceous fuels, and provide tax breaks for demonstrably economical technology and business. A duty should be imposed on the import of energy-demanding technology, and, on the contrary, economical technology that utilizes renewable sources should be exempt from fees. At the same time, the sale of energy abroad should not be supported.

On October 19, 2015, the Government of the Czech Republic approved new territorial ecological mining limits in the Bílina Quarry via Resolution No. 827, whereby mining limits will be stipulated $500 \mathrm{~m}$ from the municipality's built-up area. In the context of this Resolution, the Government of the Czech Republic assessed:

- the economic impacts in terms of the considered variants of the suspension of coal mining limits in the territory of North Bohemia,

- social impacts on individual municipalities and on the Ústí nad Labem region,

- analysis of the need for brown coal supplies for the heating industry,

- quantification of the environmental and health impacts of the open-cast mining of brown coal in the Bílina and Czechoslovak Army quarries, 
- use of extracted brown coal in combustion processes for the production of electricity and heat on the territory of the Czech Republic [2].

With the suspension of mining limits, the anthropogenic burden on the landscape around the Bílina Quarry will also increase. After the end of brown coal mining in the Most basin, pressure will be placed here on the development of alternative energy sources. Thus, it is essential to analyze the potential of these forms of energy in the model area in order to fulfill the energy consumption requirements of everybody who is currently dependent on its production by the combustion of brown coal.

\section{Materials and Methods}

The area of interest is the Most basin located in the northern part of the Czech Republic. Intensive extraction of brown coal has influenced a wide area, first of all the Chomutov, Most, Teplice and Ústí nad Labem districts. The greatest problem in the entire area is air pollution, caused by thermal power stations, heating plants, open surface coal mines and chemical plants. The long-term burden on the environment in the past was the cause of its deteriorated condition, with some of its components also reflected in the poor health condition of the inhabitants. The area is severely damaged, not only from an environmental point of view (landscape degradation, air pollution, etc.), but economic and social problems also occur there. Landscape management of the area is based on restoration and reclamation processes, which ensure integration of the damaged landscape back to the environment.

Essential material used for writing the article was Annual Report on the Operation of the Czech Energy System [3], which is focused on individual shares of energy sources, including renewable ones, in the Czech Republic. Installed capacities of specific renewable sources in the model area were available online within web pages of companies that are concentrated on specific renewable source of energy (see References). One of the methods was to study those materials very thoroughly. Professional experience and results of several researches done by Faculty of Environment of the J. E. Purkyne University provided necessary information to analyze potential of individual kind of renewable source considering geographical conditions of the model area. It must be said that economical aspect was not considered and further analysis is needed. The same cause is a geothermal potential of the area. Future of this source is significant for the area, but it requires more research support. There is a unique opportunity to define future of the area, with respect to the energy sources, after the termination of coal mining.

The data analysis consisted of summing up the individual installed capacities (kW) of specific energy resource (solar, wind, water, biogas) in each district of the model area. The data were processed in Microsoft Excel. The overall comparison of installed capacities (MW) of renewable energy resources for the whole area was summarized into one graph also in Microsoft Excel. 


\section{Results and Discussion}

In order to ensure the sustainable development of the model area after the end of mining and the use of brown coal in the power industry, we have to carry out a detailed analysis of the potential of renewable sources to ensure that society's energy demands are covered. The essential part of our research was to indentify, and summarize the current installation of renewable energy resources.

\subsection{Solar Power Stations}

For now, the anthropogenically burdened territory of North Bohemia has the highest installed capacity within the scope of RES energy from solar sources (102.28 MW), as set forth in Table 1 [4]. The power plants are situated mostly in the central part of the region under the Ore Mountains.

However, this is not an efficient or sustainable choice, as this high installed capacity came about because the construction of a solar power station was economically advantageous while a subsidy program was in place. That is why all of the power plants in this region were built between the years 2008-2010. This was caused by the abnormal and unsuitable construction of solar farms without taking into account the return on investment or the suitability of the installation. Moreover, the seasonal and changing climate does not guarantee stable conditions for the production of energy from the Sun. At the same time, valuable land was removed from the Agricultural Land Fund.

\subsection{Wind Power Stations}

As a landlocked state, the Czech Republic does not have very good conditions for the utilization of wind. However, contemporary technology can easily deal even with fluctuating wind velocity, relatively frequent change of wind direction and frost. The current trend is the construction of ever larger machines. The reasons are the lower specific costs of energy production, and the maximum utilization of localities, of which there is a limited number. However, thanks to geographic conditions, the model area has the potential for the utilization of wind energy, as the field of average wind velocity at an altitude of $100 \mathrm{~m}$ in the Ore Mountains area is 7.5 and over (Figure 1). To calculate the field of average wind velocity at an altitude of $10 \mathrm{~m}$ above the surface, the same process and input data was used as for the "wind map" at an altitude of $100 \mathrm{~m}$ above the ground.

Table 1. Installed capacity of solar power in model area [kW] [4].

\begin{tabular}{cc}
\hline District & Installed capacity $[\mathrm{kW}]$ \\
\hline Chomutov & $46,709.00$ \\
Most & 6568.71 \\
Teplice & $38,680.18$ \\
Ústí nad Labem & $10,319.50$ \\
Total & $\mathbf{1 0 2 , 2 7 7 . 3 9}$ \\
\hline
\end{tabular}




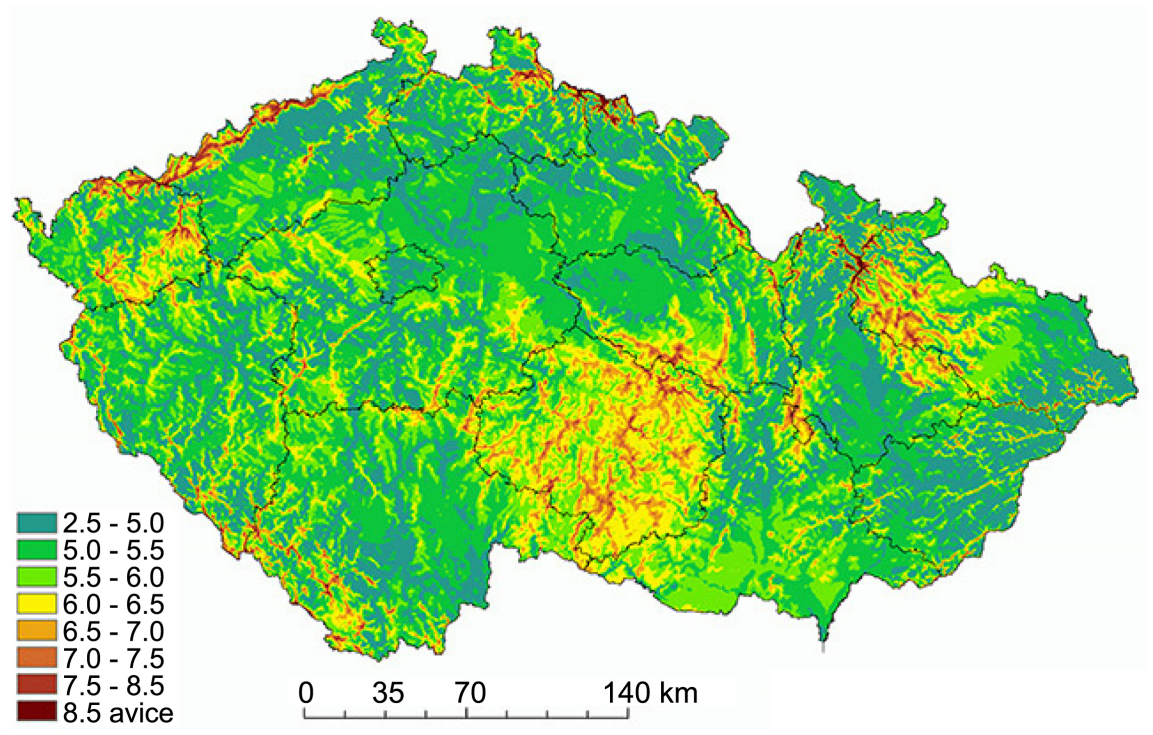

Figure 1. Average wind speed in $100 \mathrm{~m}$ over the surface [6].

The resulting wind map is a synthesis of the calculation of three models used on a long-term basis in the Institute of Atmospheric Physics at the Czech Academy of Sciences: VAS, WAsP and PIAP [5]. Table 2 describes all the wind power plants installed in the mountainous areas of the model region, whereby the largest one, with an installed output of $42,000 \mathrm{~kW}$, is found in the municipality of Krystofovy Hamry in the Chomutov district.

\subsection{Hydroelectric Power Stations}

Energy obtained from hydroelectric power plants, particularly from power plants of above $10 \mathrm{MW}$, recorded a significant overall growth in the Czech Republic in 2016 compared to the previous year, from 793,010 MWh (in 2015) to 947,388 MWh (in 2016). It was the same in the case of small hydroelectric power plants of up to $10 \mathrm{MW}$, where the gross electricity generation increased from 1,001,797 MWh (in 2015) to 1,053,100 MWh (in 2016) [3]. There are a total of 7 hydroelectric power plants in the model area, but only one of these is ranked as large. This is the Střekov constant load power plant, with an installed output of 19.5 MW, which is located on the locks of the Elbe River (Table 3).

\subsection{Biogas}

Biogas stations are modern and environmentally friendly facilities which are regularly operated in the Czech Republic and around the world. They process a wide range of materials and waste of organic origin via an anaerobic digestion process, without air access, in closed reactors. The result of the process is biogas, for now most commonly used for the production of electricity and heat, as well as digestate, which can be used as a high-quality fertilizer (similar to compost) [8]. There are a total of 12 biogas stations in the model area, of which half process products from agriculture, 3 utilize waste from sewage treatment plants, and 3 utilize landfill 
Table 2. All wind power stations installed in the model area [kW] [7].

\begin{tabular}{ccc}
\hline Title & District & Installed capacity $[\mathrm{kW}]$ \\
\hline Loučná & Chomutov & 1800 \\
Kryštofovy Hamry & Chomutov & 42,000 \\
Rusová-Podmíleská výšina & Chomutov & 7500 \\
Hora Svatého Šebestiána & Chomutov & 4500 \\
Nová Ves I & Most & 1500 \\
Nová Ves II & Most & 1500 \\
Strážní Vrch & Most & 8200 \\
Mníšek (Nová Ves) & Most & 2000 \\
Klíny & Most & 4000 \\
Nové město-Vrch tř́ pánů & Teplice & 6000 \\
Habartice u Krupky & Teplice & 4100 \\
Petrovice & Ústí n/L & 4000 \\
\hline
\end{tabular}

Table 3. All hydroelectric power stations in the model area [3].

\begin{tabular}{|c|c|c|c|c|c|}
\hline Title & $\begin{array}{c}\text { Installed } \\
\text { capacity } \\
\text { [MW] }\end{array}$ & $\begin{array}{c}\text { Production } \\
\text { [GWh] }\end{array}$ & Launch & Watercourse & District \\
\hline Střekov & 19.5 & 96 & 1936 & Labe & Ústí n/L \\
\hline Nechranice & 10 & 61 & 1968 & Ohře & Chomutov \\
\hline Meziboří & 7.6 & 7.6 & 1964 & Flájský potok & Most \\
\hline Hradiště & 3.2 & 8.2 & 1976 & Přísečnice & Chomutov \\
\hline $\begin{array}{c}\text { Kadaňský } \\
\text { stupeň }\end{array}$ & 2.28 & 10.2 & 1972 & Ohře & Chomutov \\
\hline Želina & 0.64 & $\ldots$ & 1994 & Ohře & Chomutov \\
\hline Fláje & 0.016 & & 1964 & Flájský potok & Most \\
\hline
\end{tabular}

gas (Table 4). The largest biogas station is found in the municipality of Málkov in the Chomutov district. Its installed output is $800 \mathrm{~kW}$, whereby the station accepts raw materials such as poultry bedding, corn silage, abattoir waste, kitchen waste, freshly mowed grass, sediment from treatment plants and digestate for recycling [9].

\subsection{Geothermal Power}

Geothermal energy is now becoming one of the most attractive sources of renewable energy. The geothermal potential in the individual parts of our region varies considerably, particularly in relation to geothermal, geological and hydrogeological conditions. When incorporating the territory of a certain region, we must divide it into areas that are most suitable for the utilization of geothermal energy for individual buildings and areas that are suitable for larger sources that can be used for the large-scale supply of heat or electrical energy production. 
Table 4. Biogas power stations in the model area [kW] [10].

\begin{tabular}{cccc}
\hline Title & Type & District & $\begin{array}{c}\text { Installed capacity } \\
{[\mathrm{kW}]}\end{array}$ \\
\hline Ahníkov & Agricultural & Chomutov & 800 \\
Velké Chvojno & Agricultural & Ústí n/L & 750 \\
Všebořice & Agricultural & Ústí n/L & 550 \\
Bystřany & WTP & Teplice & 280 \\
Most-Chanov & WTP & Most & 140 \\
Neštěmice & WTP & Ústí n/L & 460 \\
Modlany & Landfill biogas & Teplice & 400 \\
Vysoká pec-Jirkov & Landfill biogas & Chomutov & 190 \\
Litvínov CELIO a.s. & Landfill biogas & Most & 630 \\
Hrobčice-Razice & Agricultural & Teplice & 659 \\
Moldava & Agricultural & Teplice & 150 \\
Odolice & Agricultural & Most & 550 \\
\hline
\end{tabular}

WTP-Wastewater treatment plant.

Based on experience from other countries with similar geological structures, the Czech Republic also has potential geothermal energy sources. Heat flow anomalies have been registered in the area of the Ohárecko Rift, i.e. the Podkrusnohorí region, the western part of the Czech chalk table and the Ostravsko-Karvinská basin. These are so-called low temperature hydrothermal sources, i.e. to a temperature of 100 degrees, and the geothermal energy of so-called hot dry rocks, whose potential at depths of $3000-5000 \mathrm{~m}$ is considerably higher. Research into, and utilization of, these sources should be supported more in the future [11]. Geothermal energy is utilized in the model area, particularly in the city of Ustí nad Labem, where it is used to heat swimming pools; since May 2006 it has also been used to heat the Ústí nad Labem Zoological Garden. In Decín, there is a unique project which utilizes geothermal energy for heat production. A heating plant on Benesovská Street has been operating since 2002. It is the only one in the Czech Republic which uses geothermal energy, and it supplies half of the city with heat. In November 2006, the digging of an experimental borehole for a geothermal power plant began in Litomerice-when it is completed, it is expected to be 2500 metres deep. If the measurement results are favourable, two more boreholes-this time production boreholes-will begin to be dug. These boreholes are expected to reach a depth of as much as 5000 metres. The power plant will be based on the HDR method, which has not yet been used in Central or Eastern Europe. This method consists of water being pumped into one borehole and drawn from another, whereby it is heated at depth. It involves the closed circulation of a media-water. Thermal energy can be converted to electrical energy. In the winter, the energy will be used mainly for heating, while in the summer it will be used to generate electrical energy. The costs of digging the boreholes and constructing the geothermal power plant are expected to be 
around CZK 1.11 billion, of which part will be funded by the EU. The power plant is to have a thermal output of $50 \mathrm{MW}$ and an electrical output of $5 \mathrm{MWe}$ [12].

\subsection{Summary and Discussion}

A comparison of individual districts in terms of individual renewable energy sources is shown in Figure 2. From previous chapters, it follows that the largest proportion of renewable energy sources is taken up by solar power plants (108.21 MW), which are nevertheless not regarded as a sustainable method of obtaining energy, particularly due to the occupation of the ALR (agricultural land resources) and unfavorable returns on investments. Photovoltaic cells are mainly used in the Chomutov (47.3 MW) and Teplice (40.82 MW) districts. In comparison, wind power plants have much better potential in higher areas of the model region, as there are favorable wind conditions there. A map of average wind speed in 100 m over the surface [6] goes hand in hand with our assumption, that this is a suitable renewable source, but economic costs are not considered in this case. In total, 86.8 MW have been installed in the model area, mainly in the Chomutov district (55.8 MW). In third place in the utilization of renewable energy sources are hydroelectric power plants, which have a share of $43.24 \mathrm{MW}$ of the total installed output; of this, the largest power plant is in the Ustí nad Labem district $(19.5$ MW). This kind encounters problems especially with the constructions within the hydroelectric power plant and with the nature of the flow of rivers in the model area. In comparison with other renewable energy sources, the utilization of biogas is negligible (4.2 MW) (Figure 2), but wider use should be considered, because biogas power stations accept raw materials and waste from agriculture [9]. Geothermal energy has a considerable potential in the model area, but requires

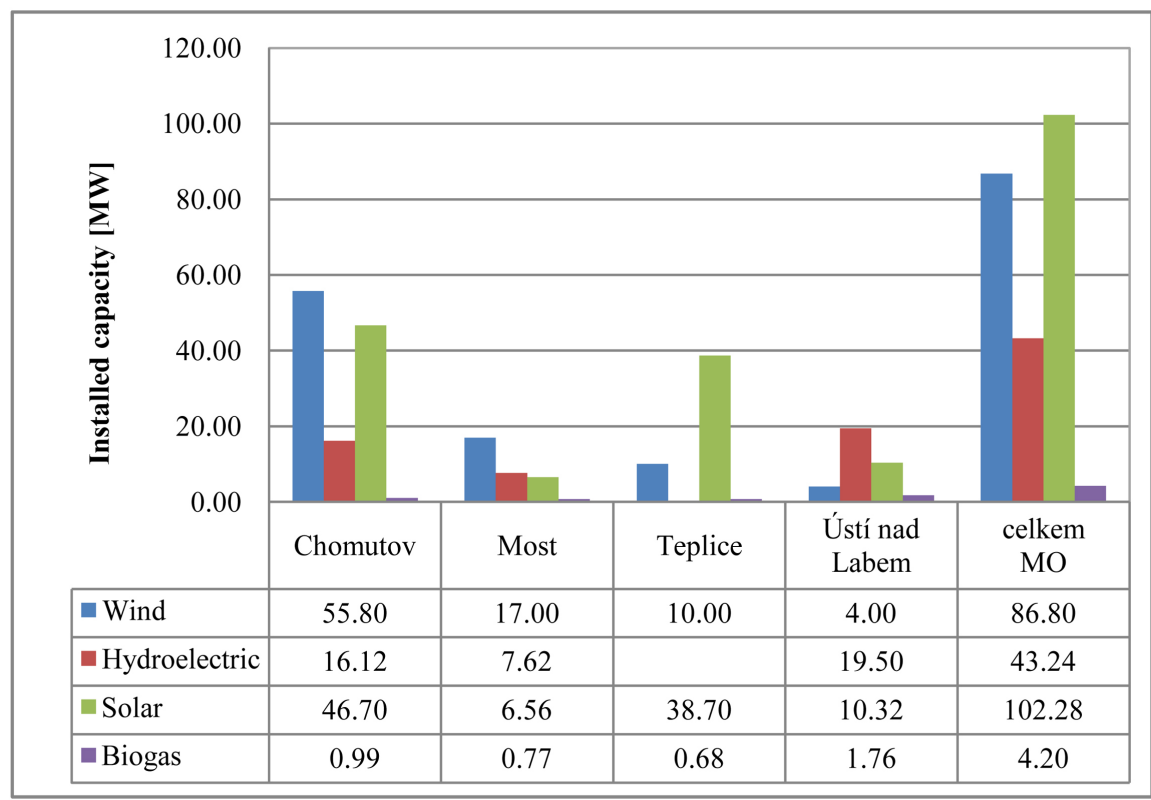

Figure 2. Overview of installed capacity of renewable resources in the model area [MW]. 
more intensive research and support as the Podkrusnohorí region is located near the heat flow anomalies [11].

\section{Conclusion}

The area of interest (Chomutov, Most, Teplice and Ústí nad Labem regions) has a unique opportunity to define future of energy sources. This topic should be dealt with now, before the termination of brown coal mining to ensure sustainable development of the area. Current installed capacities of individual kinds of renewable sources are: 108.21 MW of solar power, 86.80 MW of wind power, 43.24 MW of hydro electrical power and 4.2 MW of biogas power. The conclusion is that the best potential is in wind power thanks to the geographical conditions of the area, but further analysis of economical cost should be made in the future to prove this statement. Geothermal potential of the area is exceptional, but a further research of this energy source should be more supported.

\section{Acknowledgements}

This article was supported by project QJ1520307 entitled "Sustainable Forms of Management in an Anthropogenically Burdened Region". This project was realized with financial support from state budget resources through the KUS program, Ministry of Agriculture of the Czech Republic.

\section{References}

[1] CEZ Group (2017) Coal Power Plants in the Czech Republic. https://www.cez.cz/cs/vyroba-elektriny/uhelne-elektrarny/cr.html

[2] Government Resolution of the CR No. 827. 19. 10. (2015) Resolution of the Further Progress of Territorially Ecological Limits of Brown Coal Mining in Northern Bohemia. https://apps.odok.cz/attachment/-/down/IHOAA3RKBT3O

[3] Energy Regulatory Authority (2017) Annual Report on the Operation of the Energy System of the CR. Department of Statistics and Quality Monitoring, Prague, 35 p.

[4] Elektrárny.pro: (2017) List and Map of Photovoltaic Power Plants in the Czech Republic with the Possibility of Searching. http://www.elektrarny.pro/seznam-elektraren?kj=11\&os=17\&vn-od=\&vn-do=\&nv= \&ml $=\& l e=\& z o b r a z=$ Hledej

[5] Hanslian, D. et al. (2013) Wind Conditions in the Czech Republic at a Height of 10 $\mathrm{m}$ Above the Surface I. Institute of Physics and Atmosphere of the Academy of Science of the CR, v. v. i. http://oze.tzb-info.cz/vetrna-energie/9770-vetrne-podminky-v-ceske-republice-ve-v ysce-10-m-nad-povrchem-i

[6] Institute of Physics and Atmosphere of the Academy of Science of the CR (2009) A Map of the Average Wind Speed Range at $100 \mathrm{~m}$ Above the Surface.

http://www.osel.cz/popisek.php?popisek=22903\&img=15prumerne-rychlosti-vetruv-ceske-republice.gif

[7] Czech Society for Wind Energy (2017) Wind Power Stations in the CR-Current Installation in the Usti Region.

http://www.csve.cz/mapa-vetrnych-elektraren/ustecky

[8] ČEZ Group (2017) Renewable Sources-How Does a Biogas Station Work? 
https://www.cez.cz/cs/vyroba-elektriny/obnovitelne-zdroje/bioplyn/jak-funguje-bio plynova-stanice.html

[9] Regional Information Service (2017) Biogas Station Ahníkov. Ministry of Local Development. http://www.risy.cz/cs/vyhledavace/projekty-eu

[10] Czech Biogas Association (2017) A Map of Biogas Stations. http://www.czba.cz/mapa-bioplynovych-stanic/

[11] Blazková, M. (2010) Methodology for the Evaluation of Geothermal Potential in the Model Area of the Podkrušnohoří Area. Monography. Faculty of the Environment, J. E. Purkyně University, Ústí nad Labem, 89 p.

[12] Schuhová, T. (2010) The First Geothermal Power Plant in the Czech Republic: Liberec or Litomerice?

https://www.nazeleno.cz/energie/energetika/prvni-geotermalni-elektrarna-v-cr-libe rec-nebo-litomerice.aspx 